\title{
Cadavers as teachers: the dissecting room experience in Thailand
}

Andreas Winkelmann, Fritz H Güldner

Thailand's approach to body donors offers a good model for resolving the ethical difficulties associated with student dissection

\begin{abstract}
Anatomical dissection is a time honoured part of medical education. Nevertheless, just as the use of human tissue for research has become controversial, the use of human cadavers for teaching purposes is surrounded by ethical uncertainties. ${ }^{2-4}$ McLachlan and colleagues cited ethical problems as one of their reasons for abandoning anatomical dissection altogether in the newly founded Peninsula Medical School in Plymouth. ${ }^{5}$

At the heart of such uncertainties lies the ambiguous status of the cadaver, which carries at the same time personal and material qualities. This ambiguity is not easily resolved, which explains why the dissecting room experience can be frightening and fascinating. In this paper, we look to Thailand for a refreshing view on this issue. On the basis of personal experience, mainly from working at Naresuan University in Phitsanulok, central Thailand, we describe how a Thai medical school handles anatomical dissection quite differently from what we (as Europeans) were accustomed to. Although our findings can be largely generalised to the whole of Thailand, we cannot speak for other Buddhist countries.
\end{abstract}

\section{Source of bodies}

In Thailand, which remained an independent kingdom throughout the colonial period, Western medicine was introduced in the middle of the 19th century, mainly by American missionaries. ${ }^{6} 7$ Use of anatomical dissection for teaching was introduced around 1900. Today, gross anatomy is taught in a preclinical dissection course for second year medical students. Dissection technique and students' proficiency levels are no different from Western standards.

Cadavers are acquired through unremunerated voluntary donation. Like most Western countries, Thailand used to use unclaimed bodies for anatomical dissection, which resulted in a shortage of cadavers until about 30 years ago. Today, it no longer has any shortage of willing donors, even though most Thais are Buddhist and remain reluctant to donate organs for transplantation because of their belief in rebirth. ${ }^{8}$ people overcome their reservations. One is that King Bhumibol has officially approved body donation-a strong incentive in Thai society. The second factor is that donors attain the highly regarded status of ajarn $y a i$, great teacher. Teachers in Thailand are respected to an extent unfamiliar to Westerners. This respect is formalised in a ceremony called waikhru (honour the teacher), which takes place annually in Thai schools and universities.

The custom of calling the donors great teacher can be traced back to the very first Thai body donor, a pro-
We found at least two factors that have helped Thai fessor of literature who was inspired to donate his body in the 1930s by the idea of remaining a teacher after death. $\mathrm{He}$ is commemorated in the anatomical museum of Siriraj Hospital, Bangkok, where his skeleton is on display.

\section{Ceremonies establish a new relationship}

The status of ajarn yai is mainly conferred by two ceremonies, which seem to be a powerful means to define the atmosphere and an ethical framework for dissection courses in Thailand: the dedication ceremony some days before the first course session and the cremation ceremony at the end of the course. These ceremonies are important events in faculty life and are attended by the highest officials and students from different years.

In the dedication ceremony, faculty members, students, relatives of the deceased, and Buddhist monks come together in the dissecting room to pray and chant. The donors (that is, the cadavers) are present and are offered ritual flower bouquets. The donors' names are read aloud and they are conferred the title of ajarn (teacher). The monks are given a meal and gifts as a symbolic way of giving to the deceased.

This ceremony is an adapted mortuary rite. A major symbolic theme is to "make merit" for the spirits of the deceased. Put simply, transferring merit helps the winyan (spirit or soul) go to heaven and increases its chances for a better rebirth. The ceremony is an introduction in a double sense of the word: it marks the beginning of the course and makes the student known to the cadaver. Rather than focusing on emotional coping (as claimed for some ceremonies attached to

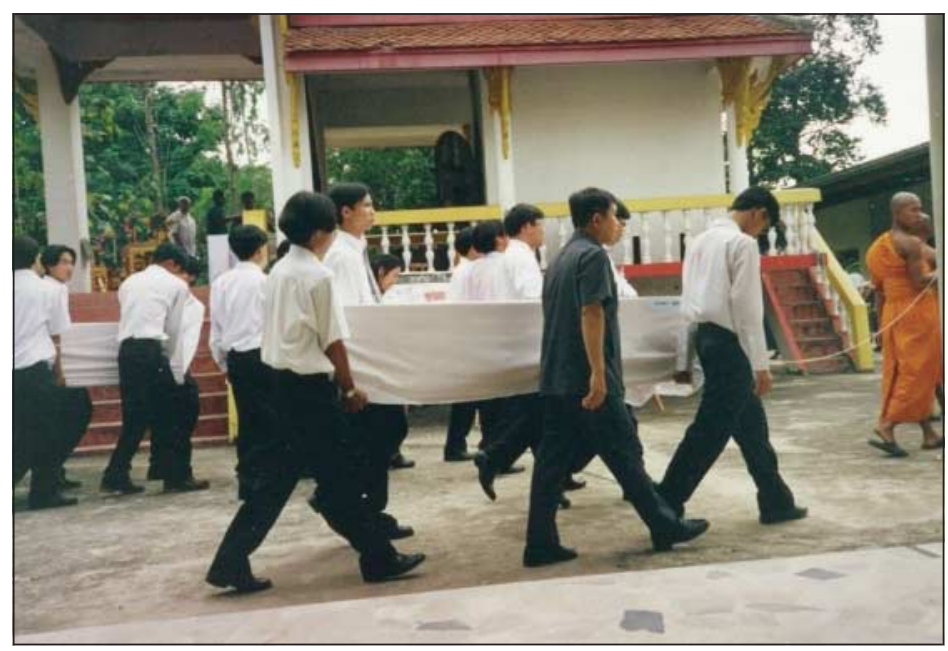

Students in Phitsanulok participating in the cremation ceremony held at the end of the dissection course

Institute of Cell Biology and Neurobiology, Centre for

Anatomy, Charité University Hospital, D-10098 Berlin, Germany

Andreas

Winkelmann assistant lecturer

Section Anatomy, Department of Basic Medical Sciences, Faculty of Medicine,

University of the

West Indies, Mona Campus, Kingston 7, Jamaica

Fritz H Güldner full professor

Correspondence to: A Winkelmann charite.de andreas.winkelmann@

BMJ 2004;329:1455-7 
Western dissection courses ${ }^{9-12}$ ), it seems to be primarily centred around establishing a new relationship. Students enter a relationship with their ajarn yai that they have learnt from early childhood: a relationship of respect for a highly valued teacher.

The cremation of the dissected bodies occasions an even bigger ceremony. It culminates in a large procession led by monks, in which the students carry their ajarn yai to the cremation building. Booklets are distributed that include the donors' pictures, their address, a short curriculum vitae, and words of condolence and gratitude from the faculty and students (box). ${ }^{13}$

\section{In the dissecting room}

Just as for Western students, the dissection of cadavers constitutes the breaking of a taboo for Thai students. Although we never saw any student showing open signs of disgust or revulsion, or of deliberately avoiding contact with the cadaver, a certain fearful expectation is palpable on the first day of the course. But this gives way to a truly relaxed atmosphere within a day or two.

During the course the cadavers are always referred to as ajarn yai, never as sop (cadaver). Respect for these teachers is paramount. One student told us she came to respect them "even more than the living teachers." Sometimes cadavers are greeted with a wai, the Thai greeting bow. Some students bring them flowers and many intend to pray for their ajarn yai at the temple (at least "after the exams"). The name, age, and cause of death of the donor are usually indicated on each dissecting table. Students can readily reproduce the name when asked to do so, and many doctors we asked still remember the name of their ajarn yai from their student days.

Even dissection of a deceased acquaintance or relative does not seem to be something beyond imagination, as it is in the West (as testified by circulating "horror stories"'). It is not uncommon in Thai anatomy departments to have the remains of former staff members, often still well remembered, on display in showcases together with a picture and flowers. We were told the story of a student whose grandfather, himself a medical doctor, had specifically asked her to dissect his body after death. She did so, and was thought to have especially good support from his spirit thereafter.

\section{Student's words of condolence for their body donor}

I would like you to know that to me and many others you are a hero.

Your sacrifice is silent, most people don't know about it. But I promise,

I will never forget you. You have taught me everything there is to be learnt both

In the book and in the facts of life. I will remember you as my great teacher forever.

From a booklet for a cremation ceremony at Mahidol University, Bangkok (original text in English)

\section{Summary points}

Thai medical schools have found a remarkable way of dealing with the ambiguities of the dissecting room

Dissection courses are accompanied by elaborate Buddhist ceremonies

The names of the body donors are well known to students and teachers

Cadavers are referred to as great teachers and treated accordingly

\section{The cadaver as a person}

Donor anonymity is obviously not an issue in Thailand as it usually is in the West. ${ }^{14}$ More than that, Thai students seem to have fewer problems with seeing the person in their cadaver. Cadavers are greeted and given flowers, they participate in ceremonies, they have a name, an age, and a history. Thai students see the cadaver as their teacher and thus attribute a social role and status to it.

In the West, the most common way of bestowing more personal qualities on the cadaver has been to regard it as the students' "first patient."12 ${ }^{15}$ However, there are important differences from the Thai situation. The "cadaver as patient" concept is a suggestion by some authors rather than a lived reality. It is certainly not taken as literally by Western students as the teacher concept is by Thai students. Nevertheless, some Western anatomists actively promote viewing cadavers as patients to encourage respectful treatment. It could be argued, however, that students who treat cadavers like patients might later treat their patients like cadavers, which could have a negative effect on medical socialisation. ${ }^{16}{ }^{17}$ Conceptualising the cadaver as a teacher avoids this problem as the cadaver is closer to a respected non-medical person than to a medical object.

\section{Ambiguous man}

Hafferty aptly called the cadaver an "ambiguous man" to denote its material as well as its personal qualities. ${ }^{18}$ We feel that Thai medical schools have found a remarkable way of handling this ambiguity. Although the cadaver can obviously be handled like an object in the dissection process, it can at the same time be seen as a respected teacher. In Thailand, the cadaver is treated much more like a social person and less like an object-or rather the difference between the two is less acutely felt than in the West.

We are not in a position to judge whether the Thai approach will produce better doctors in the end. But we do think that it allays some of the ethical difficulties in dealing with human cadavers. Indeed, medical practitioners face many ambiguities, including the need to show both detachment and empathetic care in the treatment of patients. ${ }^{19}$ Therefore, learning how to deal with such ambiguities is in itself an important aspect of 
medical training. In this respect, the West has something to learn from Thailand.

We thank Sanjai Sangvichien, Bangkok, for background information; Wiphawi Hipkaeo, Phitsanulok, for support and many helpful comments; and the Thai teachers and students who received us with such great friendliness. We also thank Ronald Frankenberg for supervision of AW's fieldwork and Kimberly Rosegger for help with the manuscript.

Contributors and sources: Both authors have a German medical background and currently teach anatomy to medical students. This paper arose from AW's MSc dissertation in medical anthropology (Brunel University), during which he conducted two months of anthropological fieldwork (participant observation in the dissecting room and informal interviews with faculty members and students) in Phitsanulok. FHG spent over three years working as an anatomist in Thailand. AW is the guarantor. Competing interests: None declared.

1 Furness P. Consent to using human tissue. BMJ 2003;327:759-60.

2 Hafferty FW. Cadaver stories and the emotional socialization of medical students. J Health Soc Behav 1988;29:344-56.

3 Tuffs A. Von Hagens faces investigation over use of bodies without conTuffs A. Von Hagens faces
sent. BMJ 2003;327:1068.

4 Shaffer K. Becoming a physician: teaching anatomy in the digital world. N Engl J Med 2004;351:1279-81.

5 McLachlan JC, Bligh J, Bradley P, Searle J. Teaching anatomy without cadavers. Med Educ 2004;38:418-24.
6 Popp RL. American missionairies and the introduction of western science and medicine in Thailand 1830-1900. Missiology 1985;13:147-57. Suwanwela C. International co-operation and practice: a view from Thailand. Med Educ 1996;30: 401-4.

land. Med Educ 1996;30: 401-4.
Ongcharit C, Ongcharit P. Intrathoracic organ transplantation in Thailand. Transplant Proc 1998;30:3385-6.

9 Schotzinger KA, Kirkley Best E. Closure and the cadaver experience: a memorial service for deeded bodies. Omega J Death Dying 1987;18:21727.

10 Dyer GS, Thorndike ME. Quidne mortui vivos docent? The evolving purpose of human dissection in medical education. Acad Med 2000;75:969-

11 Hull SF, Shea SL. A student-planned memorial service. Acad Med 1998;73:577-8.

12 Bertman SL, Marks SC. Humanities in medical education: rationale and resources for the dissection laboratory. Med Educ 1985;19:374-81.

13 Olson GA. Thai cremation volumes: a brief history of a unique genre. Asian Folklore Studies 1992;51:279-94.

14 Sukol RB. Building on a tradition of ethical consideration of the dead. Hum Pathol 1995;26:700-5.

15 Segal DA. A patient so dead: American medical students and their cadavers. Anthropol Q 1988;61:17-25.

16 Lella JW, Pawluch D. Medical students and the cadaver in social and cultural context. In: Lock M, Gordon DR, eds. Biomedicine examined. Dordrecht: Kluwer, 1988:125-53.

17 Good BJ. Medicine, rationalitiv, and experience: an anthropological perspective. Cambridge: Cambridge University Press, 1994

18 Hafferty FW. Into the valley: death and the socialization of medical students. Hafferty FW. Into the valley: death and the
New Haven: Yale University Press, 1991.

19 Rosenfield PJ, Jones L. Striking a balance: training medical students to provide empathetic care. Med Educ 2004;38:927-33.

(Accepted 7 September 2004)

\section{The relentless therapeutic imperative}

\section{Charlotte Paul}

Decisions about care near the end of life are always difficult, even more so when a relative has a progressive neurological illness

\section{Sweet rose, whose hue angry and brave \\ Bids the rash gazer wipe his eye, \\ Thy root is ever in its grave, \\ And thou must die.}

\section{From Virtue by George Herbert}

This is a story about the experience of making decisions about when to choose interventions near the end of life. It is about the difficulty of making those decisions for a close relative. It is not a story about good and bad doctors, though their recognition of the difficulties can make a difference. And it is about a special difficulty faced by people with a long term progressive neurological illness and their close relatives. As relatives, we have been caring for people with illnesses whose potentially lethal complications can be managed medically so that the person stays alive with ever increasing disability. We fear that dying will be drawn out interminably, past our capacity to care. Ideas of autonomous decision making by the ill person are not sufficiently helpful-nor is there just one choice to make about whether to accept interventions, but many decisions, each one closely related to particular circumstances. We would be helped by doctors and nurses who were prepared to advise when further treatment might be too burdensome.

\section{Why did I feel so appalled?}

When the consultant recommended the PEG (percutaneous endoscopic gastrostomy) I was appalled, and in my shock wanted to tell him that he could have my husband too, if he liked, as his husband, well maybe as his brother. Speaking from among his circle of junior doctors and nurses around my husband's bed, the consultant had responded to my observation that, as well as the new infection, my husband had been getting very thin. He said, "There is an operation, to put a tube directly into your stomach to feed you. It is quite safe. You will put on weight and feel better. Do you want it?" My husband nodded. "Good, we'll get it organised." Perhaps we should talk more about it, I ventured. I took aside the registrar, whom I knew: "Can I talk to you?" " If you like," she said; "don't let yourself be rushed into anything."

I went back to work in tears, angry and dismayed, and told my friends and colleagues about the prospect of the stomach tube. Why did I feel so appalled? Why did I feel it in my guts? It was partly the further assault on his frail body, partly the bags of ugly stuff I'd seen in the ward kitchen-like predigested food in a blood bag. Partly it was the memory of another younger man I'd once seen lying in a bed beside my husband's, unable to move or speak, visited occasionally by a nurse to put stuff into his stomach, but by no one else. And partly it was the shape of life. How long can anyone drag out an illness? And on top of the neurological damage of multiple sclerosis there were the infections-of bladder and bowel and lungs in rotation-each one requiring an emergency admission, first (for many years) from home, then in the last three years, from the local geriatric hospital. There were now two days in the week that I generally didn't see him. Sunday was always his
Department of Preventive and Social Medicine, University of Otago Medical School, Dunedin, New Zealand

Charlotte Paul associate professor of epidemiology

charlotte.paul@ stonebow.otago.ac.nz

BMJ 2004;329:1457-9 